\title{
Cinemas e audiovisualidades queer/kuir/cuir no Brasil e na América Latina
}

Neste segundo volume do Dossiê Cinema e Audiovisualidades queer/kuir/cuir no Brasil e na América Latina, damos continuidade às reflexões sobre os deslocamentos teóricos, conceituais, políticos e estéticos produzidos pelos estudos sobre cinema e audiovisualidades dissidentes no contexto brasileiro e latino americano. Assim como no primeiro volume, esta segunda edição apresenta um conjunto de textos de tessitura variável, desde artigos científicos a ensaios que passeiam pela crítica cinematográfica, bem como textos que apresentam formatos autorais e experimentais.

O artigo Notas sobre (in)visibilidade dissidente e políticas públicas no audiovisual brasileiro, de Juliana Ribeiro Pinto Bravo, abre este segundo volume. O trabalho traz uma contribuição ainda original para os estudos sobre cinema no Brasil, pois deixa de lado as tradicionais análises de obras fílmicas para se ater na presença das populações LGBT no contexto das políticas públicas de incentivo e fomento ao setor audiovisual. Tendo como ponto de partida o boom da produção independente no país após a criação da Lei 12.485/11, impulsionado pelas cotas de tela e novas linhas de financiamento para cinema e TV, a autora investiga as medidas e mecanismos que possibilitaram, nos últimos anos, novas emergências e visibilidades de sujeitos e corpos dissidentes no cinema brasileiro.

Figura importante nesta mesma cena artística e cultural protagonizada por artistas travestis, bichas e drag queens que emergiu na última década, a cantora e atriz Linn da Quebrada marca presença em três artigos desta segunda edição do Dossiê. Em Autoria deslocada e audiovisualidades engajadas em Bixa Travesty, Daniel Zacariotti e Rose de Melo Rocha se dedicam a estudar as inflexões das tradicionais noções de autoria no campo cinematográfico através do longa-metragem Bixa Travesty (Kiko Goifman, Claudia Priscilla, 2018). As autoras elaboram seu estudo a partir da presença de Linn no campo da atuação e na elaboração do roteiro, estando em uma constante rasura e partilha com a figura do diretor e da diretora. Para tanto, as pesquisadoras também mobilizam operações teóricas como "cinema de sujeito", "artivismo musical" e "dissidências de gênero".

Há, ainda, um segundo texto no qual o longa metragem Bixa Travesty marca presença, dessa vez, dividindo espaço com os filmes Cuceta (Tertuliana Lustosa, 2017) e A Rosa Azul de Novalis (Gustavo Vinagre e Rodrigo Carneiro, 2019). Trata-se do artigo A resistência de corpos dissidentes no audiovisual brasileiro através da região anal nas telas, escrito em conjunto por Vicente de Paula Nascimento Leite Filho e Gabriela Pereira de Freitas. Aqui, as autoras investigam como as imagens do cu nestas três obras desenham rupturas na paisagem colonial, racista e generificada, especialmente na 
medida em que tais fricções são produzidas por um protagonismo ético e estético de bichas e travestis. $O$ artigo ainda mobiliza uma interessante bibliografia teórica e conceitual a respeito do cu, desde o debate intelectual francês de Gilles Deleuze e Félix Guattari, passando por autoras brasileiras como Larissa Pelúcio, Jota Mombaça e Pedra Costa, e alcançando espanhóis como Preciado, Sáez e Carrascosa.

Já o terceiro trabalho no qual Linn da Quebrada recebe atenção trata-se do ensaio Corpas negras em rexistências cuir: olhares opositores e multidões queer nos videoclipes Absolutas e blasFêmea / Mulher, de Linn da Quebrada, produzido por Ed Borges e Gabriela Reinaldo. Nesta pesquisa, é especialmente a tessitura híbrida e experimental dos videoclipes da artista que ganha atenção, sobretudo a partir de noções como performance, tempo e espaço. O trabalho tensiona não apenas operações conceituais importantes dos estudos sobre videoclipe, como também os articula com a teoria de pesquisadores reconhecidos nos campos dos estudos de raça, gênero e sexualidade, a exemplo dos trabalhos de Bell Hooks e Paul Preciado.

Este segundo volume do dossiê ainda conta com três artigos que se dedicam à analises de obras fílmicas. A primeira delas é Efeitos performativos na (des) construção de discursos de gênero e sexualidade no filme $O$ céu sobre os ombros: uma análise a partir da direção de fotografia, de Agnes Cristine Souza Vilseki e Jamil Cabral Sierra. O trabalho articula os efeitos de real construídos e tensionados pela linguagem cinematográfica, sobretudo pela direção de fotografia no filme $O$ céu sobre os ombros (Sérgio Borges, 2010) e em diálogo com os estudos de gênero e sexualidade. Para sustentar sua análise, as pesquisadoras se apropriam dos conceitos de dispositivo de sexualidade, de Michel Foucault, e de performatividade de gênero, de Judith Butler, que possibilitaram investigar como a fotografia cinematográfica atua na construção de discursos que operam entre capturas e resistências.

Já o trabalho de Carlos Frederico Bustamante Pontes, intitulado O beijo da mulher aranha (1981/1985) e as identificações e desidentificações pelas quais nos constituímos subjetivamente, oscila entre análise fílmica e crítica cinematográfica. O texto se sustenta em uma perspectiva espectatorial do próprio pesquisador que, após 36 anos de seu primeiro encontro com a peça teatral $O$ beijo da mulher aranha (dirigida por Ivan de Albuquerque, 1981), produz agora uma reflexão em conjunto com o longa-metragem de mesmo nome, dirigido por Héctor Babenco, em 1985.

A terceira e última análise fílmica nos é apresentada por Cecilia Nuria Gil Mariño, com seu artigo Fisuras, desvíos y transgresiones a las leyes de los machos: Masculinidades en O menino e o vento y A intrusa de Carlos Hugo Christensen. Como já indica o título, a pesquisa de Mariño analisa as desestabilizações das matrizes binárias do masculino e do feminino em dois filmes do cineasta argentino Carlos Hugo 
Christensen: O menino e o vento (1966) e A Intrusa (1979). Tendo este gesto como ponto de partida, a pesquisadora analisa, por um lado, a paisagem como metáfora de liberdade e opressão para o delineamento dos personagens homens; por outro, também indaga como os processos de tensão entre a transgressão, a ordem, o desejo e a condenação desses homens frente os tribunais do patriarcado adotam características distintas nas duas obras.

Por fim, o pesquisador Luís Fernando Moura apresenta seu ensaio Aprender o quê com cada outro destes corpos? Da rave a um léxico das aparições. Neste trabalho de investigação em curso, o autor parte da sua experiência em uma rave na cidade de Recife, Pernambuco, e se dedica a refletir sobre a convivência entre corpos "mais ou menos normais" à beira de uma aparição limítrofe, e que instauram intervalos e continuidades, à maneira de um jogo entre suspensão pela singularidade e proposição para a coletividade.

Agradecemos enormemente a Gabriela Ramos de Almeida, editora da Rebeca, pelo convite para esta edição, a todas as pessoas envolvidas no processo de avaliação e revisão dos textos, a todes autores que contribuíram com seus textos e pesquisas, e a Thayse Madella, pelo trabalho de secretaria e diagramação deste dossiê. Ficamos muito contentes que a proposta de um dossiê sobre questões queer/kuir/cuir tenha rendido mais que um número da Rebeca, que a centelha de modos de vida, percepções e expressões audiovisuais queer/kuir/cuir se coloquem em evidência, iluminando o tempos sombrios que atravessamos.

Desejamos a todes uma ótima experiência de leitura!

Alessandra Brandão

Dieison Marconi 